\title{
Is there a measurable association of epidural use at cystectomy and postoperative outcomes? A population-based study
}

\author{
R. Christopher Doiron, MD;' Melanie Jaeger, MD,2 Christopher M. Booth, MD, ${ }^{3,4,5}$ Xuejiao Wei, MD,5 \\ $D$. Robert Siemens, $M D^{1,3,5}$
}

'Department of Urology; ${ }^{2}$ Department of Anesthesiology and Perioperative Medicine; ${ }^{3}$ Department of Oncology; ${ }^{4}$ Public Health Sciences; ${ }^{5}$ Division of Cancer Care and Epidemiology, Queen's University Cancer Research Institute; Queen's University, Kingston, ON, Canada

Cite as: Can Urol Assoc J 2016;10(9-10):321-6. hittp://dx.doi.org/10.5489/cuaj.3856

\section{Abstract}

Introduction: Thoracic epidural analgesia (TEA) is commonly used to manage postoperative pain and facilitate early mobilization after major intra-abdominal surgery. Evidence also suggests that regional anesthesia/analgesia may be associated with improved survival after cancer surgery. Here, we describe factors associated with TEA at the time of radical cystectomy (RC) for bladder cancer and its association with both short- and long-term outcomes in routine clinical practice. Methods: All patients undergoing RC in the province of Ontario between 2004 and 2008 were identified using the Ontario Cancer Registry (OCR). Modified Poisson regression was used to describe factors associated with epidural use, while a Cox proportional hazards model describes associations between survival and TEA use. Results: Over the five-year study period, 1628 patients were identified as receiving $\mathrm{RC}, 54 \%(\mathrm{n}=887)$ of whom received TEA. Greater anesthesiologist volume (lowest volume providers relative risk [RR] 0.85, 95\% confidence interval [CI] 0.75-0.96) and male sex (female sex RR 0.89, 95\% Cl 0.79-0.99) were independently associated with greater use of TEA. TEA use was not associated with improved short-term outcomes. In multivariable analysis, TEA was not associated with cancer-specific survival (hazard ratio [HR] $1.02,95 \% \mathrm{Cl} 0.87-1.19 ; \mathrm{p}=0.804)$ or overall survival (HR 0.91, 95\% Cl 0.80-1.03; $p=0.136)$.

Conclusions: In routine clinical practice, 54\% of RC patients received TEA and its use was associated with anesthesiologist provider volume. After controlling for patient, disease and provider variables, we were unable to demonstrate any effect on either short- or long-term outcomes at the time of RC.

\section{Introduction}

Radical cystectomy (RC) with urinary diversion for muscleinvasive bladder cancer (MIBC) has significant morbidity, particularly for the elderly. ${ }^{1,2}$ Major complication rates approach $30 \%$, even in centres of excellence. ${ }^{3-5}$ However, RC - accompanied with an optimal pelvic lymph node dissection - performed in combination with perioperative chemotherapy remains the gold standard for MIBC management. Continuing efforts to reduce the morbidity of this major operation are paramount.

The role of anesthesia and analgesia in the perioperative care of MIBC patients would seem to be vital to favourable outcomes. Long considered the standard of care for major abdominal surgery, ${ }^{6,7}$ intravenous patient-controlled analgesia (IV PCA) has been replaced by neuraxial analgesia, either thoracic epidural analgesia (TEA) or thoracic patient-controlled epidural analgesia (PCEA). In various surgical populations, studies have shown epidural analgesia as superior in terms of improving early outcomes, including improved perioperative pain control, decreased early complications, and decreased time to return of bowel function. ${ }^{8,9}$ Recommendations for the Enhanced Recovery After Surgery (ERAS) programs therefore include TEA for large open abdominal procedures ${ }^{10,11}$ and TEA is has been recommended as the postoperative analgesic technique of choice for MIBC patients undergoing RC. ${ }^{12}$

In addition to an improvement of early outcomes, there is a body of literature to suggest that perioperative regional analgesia may attenuate cancer recurrence. Early retrospective studies in breast, colon, and prostate cancer populations ${ }^{13-15}$ reported improved recurrence- and metastasis-free survival in patients who received neuraxial analgesia. Despite these encouraging early findings and a plethora of basic science evidence to support the biologic plausibility, ${ }^{16-18}$ more recent analyses have been less encouraging. ${ }^{19,20}$ This phenomenon has not been specifically investigated in the RC population.

Population-based studies are able to provide further insight into outcomes in routine clinical practice. We undertook this contemporary, population-based study to describe the use of TEA at the time of RC in routine clinical practice and evaluate its association with short- and long-term outcomes.

\section{Methods}

We retrospectively examined factors associated with the use of TEA and its impact on outcomes in a population-based 
cohort study of patients undergoing RC in the province of Ontario between 2004 and 2008. Patients who underwent $\mathrm{RC}$ were identified using the Ontario Cancer Registry (OCR). The OCR is a population-based registry capturing demographic and diagnostic data on at least $98 \%$ of incident cancer cases in the province of Ontario. ${ }^{21}$ The OCR provided the following: International Classification of Disease site and histology codes, date of diagnosis, place of residence at diagnosis, vital status, date, and cause of death.

This registry data was then linked to a collection of administrative health databases, as previously described, ${ }^{22}$ using unique encoded identifiers and analyzed at the Institute for Clinical Evaluative Sciences (ICES). Information about hospital care, physician providers, and surgical interventions were provided from the Canadian Institute for Health Information (CIHI). It is known that participation in the collection of separation records throughout the province of Ontario is consistent and complete. ${ }^{23}$ Although information on pathological stage is missing in these datasets, a team of trained data abstractors reviewed pathology reports obtained from the OCR and entered variables according to a predefined study protocol.

Comorbidity was classified using the Charlson index ${ }^{24}$ adapted by Deyo and colleagues. ${ }^{25}$ Previously described methods of determining socioeconomic status were used. ${ }^{22}$ Chemotherapy within 16 weeks after surgery was classified as adjuvant chemotherapy. Given provider volume's well-established measure of overall surgical quality, ${ }^{26}$ we explored its association with epidural use. We also evaluated the association between anesthesiologist volumes and epidural use. Determination of surgeon and hospital volume was determined as previously described; ${ }^{26}$ we used a similar approach to define anesthesiologist volume. As annual RC volume among anesthesiologists in Ontario was very low, we applied an a priori composite value that included both RC and similarly complex major colorectal procedures.

The study's primary objectives were to: 1 ) describe use of epidural analgesia in routine practice; 2 ) evaluate factors associated with practice; and 3) describe the association between epidural analgesia and patient outcome. Descriptive statistics were used to describe TEA use in this population. To examine factors associated with TEA use, a modified Poisson regression model was used. Logistic regression was used to examine factors associated with 90-day mortality. The Cox proportional hazards model was used to evaluate the association between patient-, disease- and treatment-related factors (including TEA use) with cancer-specific (CSS) and overall (OS) survival. Results were regarded as statistically significant with a p value of $<0.05$. SAS version 9.3 (SAS Institute, Cary, NC, U.S.) was used for all analyses. This study was approved by the Research Ethics Board at Queen's University, Kingston, $\mathrm{ON}$, and the institutional review board at Sunnybrook Health Sciences Centre, Toronto, ON, Canada.

\section{Results}

During the study period of 2004-2008, 1628 patients had $\mathrm{RC}$ for bladder cancer in the province of Ontario. Table 1 describes the cohort based on whether or not they received TEA. Of the total cohort, 887 (54\%) received a TEA, with several disease, patient, and provider characteristics associated with its use. In multivariable analysis, factors associated with TEA use included gender $(p=0.029)$, nodal status $(p=0.002)$, and anesthesiologist volume $(p \leq 0.001)$ (Table 2 ). Women were less likely to receive an epidural than men (relative risk [RR] 0.89, 95\% confidence interval [Cl] 0.79-0.99). Status of a pelvic lymph node dissection, as determined by the surgical pathology report, was also associated with TEA use (RR 0.78, 95\% Cl 0.67-0.91). Finally, higher anesthesiologist volume was significantly associated with increased TEA use (lowest volume providers RR 0.85, 95\% Cl 0.75-0.96).

In a univariate analysis of outcomes (Table 3), we observed no difference in length of stay (LOS) between those who received a TEA and those who did not. There was no difference in either 30-day ( $p=0.161)$ or 90-day readmission rates $(p=0.893)$ between the groups, nor was there a difference in 30 -day mortality $(p=0.438)$. There was a trend towards increased 90-day postoperative mortality in the nonepidural group (9\%) compared to those with an epidural $(7 \%)$, however, this did not reach significance $(p=0.104)$. TEA was not associated with 90-day postoperative mortality in multivariable analysis (Table 4).

Although in univariate analysis, a trend towards improved five-year OS was observed in those who received an epidural vs. those who did not ( $41 \%$ vs. $37 \%$ respectively; $p=0.127)$, multivariable analysis did not show a significant association between epidural and OS (Table 5). Furthermore, there was no difference between the groups in five-year CSS in univariate $(\mathrm{p}=0.937)$ or multivariable analyses (hazard ratio [HR] $1.02,95 \% \mathrm{Cl} 0.87-1.19)$. Factors associated with long-term survival include age, comorbidity, extent of disease, surgeon volume, and use of adjuvant chemotherapy (Table 5).

\section{Discussion}

We report on neuraxial analgesia use among patients with bladder cancer treated with RC in routine clinical practice in the province of Ontario. In this retrospective, populationbased study, we found that from 2004-2008 just over half of RC patients received TEA and higher-volume anesthesiologists were more likely to use TEA as a pain management strategy. TEA was also more commonly used in men than women. We found no association between TEA use and early or late patient outcomes in this population-based cohort.

Perhaps not unexpectedly, higher-volume anesthesia providers were more likely to use TEA. This supports evi- 


\begin{tabular}{|c|c|c|c|c|}
\hline & \multirow{2}{*}{$\begin{array}{l}\text { All cases } \\
n=1628\end{array}$} & \multicolumn{2}{|c|}{ Epidural } & \multirow[t]{2}{*}{$p$ value } \\
\hline & & $\begin{array}{c}\text { Yes } \\
n=887\end{array}$ & $\begin{array}{c}\text { No } \\
n=741\end{array}$ & \\
\hline Age & & & & 0.495 \\
\hline $20-59$ & 239 (15\%) & $123(14 \%)$ & $116(16 \%)$ & \\
\hline $60-69$ & 386 (24\%) & $208(23 \%)$ & $178(24 \%)$ & \\
\hline 70-79 & $646(40 \%)$ & $366(41 \%)$ & $280(38 \%)$ & \\
\hline $80+$ & 357 (22\%) & $190(21 \%)$ & $167(23 \%)$ & \\
\hline \multicolumn{5}{|l|}{ Patient-related } \\
\hline Sex & & & & 0.005 \\
\hline Male & 1,237 (76\%) & $698(79 \%)$ & $539(73 \%)$ & \\
\hline Female & 391 (24\%) & $189(21 \%)$ & $202(27 \%)$ & \\
\hline $\begin{array}{l}\text { Socioeconomic } \\
\text { status* }\end{array}$ & & & & 0.534 \\
\hline Q1 & 289 (18\%) & 159 (18\%) & $130(18 \%)$ & \\
\hline Q2 & $360(22 \%)$ & $206(23 \%)$ & $154(21 \%)$ & \\
\hline Q3 & $396(24 \%)$ & $208(23 \%)$ & $188(25 \%)$ & \\
\hline Q4 & 314 (19\%) & $176(20 \%)$ & 138 (19\%) & \\
\hline Q5 & 269 (17\%) & $138(16 \%)$ & 131 (18\%) & \\
\hline $\begin{array}{l}\text { Charlson } \\
\text { comorbidity score }\end{array}$ & & & & 0.370 \\
\hline 0 & 1,161 (71\%) & $623(70 \%)$ & $538(73 \%)$ & \\
\hline 1 & $260(16 \%)$ & $152(17 \%)$ & 108 (15\%) & \\
\hline $2+$ & 207 (13\%) & $112(13 \%)$ & $95(13 \%)$ & \\
\hline \multicolumn{5}{|l|}{ Disease-related } \\
\hline T stage & & & & 0.295 \\
\hline$<\mathrm{T} 2$ & 359 (22\%) & $194(22 \%)$ & $165(22 \%)$ & \\
\hline $\mathrm{T} 2$ & $320(20 \%)$ & $183(21 \%)$ & 137 (18\%) & \\
\hline T3 & $584(36 \%)$ & 302 (34\%) & $282(38 \%)$ & \\
\hline $\mathrm{T} 4$ & 365 (22\%) & $208(23 \%)$ & 157 (21\%) & \\
\hline $\mathrm{N}$ stage & & & & 0.003 \\
\hline $\mathrm{N}$ negative & 952 (58\%) & $530(60 \%)$ & $422(57 \%)$ & \\
\hline $\mathrm{N}$ positive & $455(28 \%)$ & $260(29 \%)$ & $195(26 \%)$ & \\
\hline NX & 221 (14\%) & $97(11 \%)$ & $124(17 \%)$ & \\
\hline $\begin{array}{l}\text { "Q1 represents the comm } \\
\text { resided; \&hospital and sur } \\
\text { cystectomies done over a } \\
\text { for <6 patients); }{ }^{*} \text { anesthes } \\
\text { cystectomy and colorecta } \\
\text { available for } 40 \text { patients). }\end{array}$ & $\begin{array}{l}\text { ies where the po } \\
n \text { volume were c } \\
\text {-year study perio } \\
\text { gist volume was } \\
\text { eections over a fiv }\end{array}$ & $\begin{array}{l}\text { orest } 20 \% \text { of th } \\
\text { lassified basec } \\
\text { d (surgeon vo } \\
\text { classified base } \\
\text { ve-year study }\end{array}$ & $\begin{array}{l}\text { Ontario popula } \\
\text { the mean nur } \\
\text { ne data were } n \\
\text { on the mean n }\end{array}$ & $\begin{array}{l}\text { er of } \\
\text { available } \\
\text { ber of } \\
\text { were not }\end{array}$ \\
\hline
\end{tabular}

dence that higher-volume centres are more adherent to care pathways and quality-of-care processes, ${ }^{27}$ which are increasingly including use of regional — and specifically for intra-abdominal procedures - neuraxial analgesia. We felt it reasonable to use a composite value for anesthesiologist volume given the small RC volume of anesthesiologists in routine clinical practice. The finding that TEA use was less frequent in women is of interest and potentially highlights perceived inequities in management and outcomes of women with bladder cancer. ${ }^{28}$

Despite its recognized importance in early outcomes in related surgical populations, ${ }^{8,9}$ there is a paucity of evidence
Table 1 (cont'd). Characteristics of 1628 patients with bladder cancer treated with cystectomy in Ontario from 2004-2008

\begin{tabular}{|c|c|c|c|c|}
\hline & \multirow{2}{*}{$\begin{array}{l}\text { All cases } \\
n=1628\end{array}$} & \multicolumn{2}{|c|}{ Epidural } & \multirow[t]{2}{*}{ p value } \\
\hline & & $\begin{array}{c}\text { Yes } \\
n=887\end{array}$ & $\begin{array}{c}\text { No } \\
n=741\end{array}$ & \\
\hline \multicolumn{5}{|l|}{ Treatment-related } \\
\hline $\begin{array}{l}\text { Adjuvant } \\
\text { chemotherapy }\end{array}$ & & & & 0.458 \\
\hline Yes & $282(17 \%)$ & $148(17 \%)$ & $134(18 \%)$ & \\
\hline No & $1,346(83 \%)$ & $739(83 \%)$ & $607(82 \%)$ & \\
\hline Surgeon volume \& & & & & $<0.001$ \\
\hline Q1 (lowest) & 276 (17\%) & $131(15 \%)$ & $145(20 \%)$ & \\
\hline Q2 & 387 (24\%) & $188(21 \%)$ & $199(27 \%)$ & \\
\hline Q3 & $434(27 \%)$ & $239(27 \%)$ & $195(26 \%)$ & \\
\hline $\mathrm{Q} 4$ & $528(32 \%)$ & $327(37 \%)$ & $201(27 \%)$ & \\
\hline Hospital volume \& & & & & $<0.001$ \\
\hline Q1 (lowest) & 249 (15\%) & $127(14 \%)$ & $122(16 \%)$ & \\
\hline Q2 & $503(31 \%)$ & $230(26 \%)$ & $273(37 \%)$ & \\
\hline Q3 & $311(19 \%)$ & $197(22 \%)$ & $114(15 \%)$ & \\
\hline Q4 & $565(35 \%)$ & $333(38 \%)$ & $232(31 \%)$ & \\
\hline $\begin{array}{l}\text { Anesthesiologist } \\
\text { volume }^{\#}\end{array}$ & & & & $<0.001$ \\
\hline Q1 (lowest) & $403(25 \%)$ & $195(22 \%)$ & $208(28 \%)$ & \\
\hline Q2 & $366(22 \%)$ & $207(23 \%)$ & $159(21 \%)$ & \\
\hline Q3 & $362(22 \%)$ & $226(25 \%)$ & $136(18 \%)$ & \\
\hline Q4 & $457(28 \%)$ & $258(29 \%)$ & $199(27 \%)$ & \\
\hline
\end{tabular}

${ }^{*}$ Q1 represents the communities where the poorest $20 \%$ of the Ontario population resided; \&hospital and surgeon volume were classified based on the mean number of cystectomies done over a five-year study period (surgeon volume data were not available for $<6$ patients); \#anesthesiologist volume was classified based on the mean number of cystectomy and colorectal resections over a five-year study period (volume data were not available for 40 patients).

supporting TEA-associated improvement of patient outcomes in RC. Evidence often quoted supporting use of TEA in reduction of short-term complications in RC come from the ERAS literature. ${ }^{29}$ The ERAS studies are investigating several perioperative interventions simultaneously, so to attribute improvements in short-term complications to one aspect of the intervention - TEA — is not likely appropriate. Our best evidence then, must be extrapolated from mixed surgical populations.

Our findings are consistent with previous studies in the RC population showing no benefit to TEA in early outcomes. In their single-centre, retrospective analysis of 131 RC patients, Toren et $\mathrm{al}^{30}$ noted no difference in early outcomes, including pain scores and LOS, between those who received IV PCA and PCEA. Gomez et $\mathrm{al}^{31}$ similarly showed no differences in complications or survival between RC patients receiving IV PCA and TEA in their retrospective cohort of 274 patients. In a more recent series of 302 patients undergoing RC, aside from modest decreased amounts of total opioid requirement, Winer et $\mathrm{al}^{32}$ observed no difference in early outcomes - including LOS, return of bowel function, and early complications - between those who received 


\begin{tabular}{|c|c|c|c|}
\hline \multirow[t]{2}{*}{ Characteristic } & \multirow[t]{2}{*}{$\begin{array}{c}\text { Epidural } \\
\text { use (\%) }\end{array}$} & \multicolumn{2}{|c|}{ Multivariable analysis } \\
\hline & & RR (95\% Cl) & p value \\
\hline \multicolumn{4}{|l|}{ Patient-related } \\
\hline Age & & & 0.405 \\
\hline $20-59(n=239)$ & $51 \%$ & Ref & \\
\hline $60-69(n=386)$ & $54 \%$ & $1.06(0.91-1.24)$ & \\
\hline $70-79(n=646)$ & $57 \%$ & $1.12(0.97-1.29)$ & \\
\hline $80+(n=357)$ & $53 \%$ & $1.08(0.92-1.26)$ & \\
\hline Sex & & & 0.029 \\
\hline Male $(n=1237)$ & $56 \%$ & Ref & \\
\hline Female $(n=391)$ & $48 \%$ & $0.89(0.79-0.99)$ & \\
\hline $\begin{array}{l}\text { Charlson comorbidity } \\
\text { score }\end{array}$ & & & 0.547 \\
\hline $0(n=1161)$ & $54 \%$ & Ref & \\
\hline $1(n=260)$ & $58 \%$ & $1.07(0.95-1.19)$ & \\
\hline $2+(n=207)$ & $54 \%$ & $1.00(0.88-1.14)$ & \\
\hline \multicolumn{4}{|l|}{ Disease-related } \\
\hline T stage & & & 0.291 \\
\hline$<\mathrm{T} 2(\mathrm{n}=359)$ & $54 \%$ & Ref & \\
\hline T2 $(n=320)$ & $57 \%$ & $1.07(0.94-1.22)$ & \\
\hline T3 $(n=584)$ & $52 \%$ & $0.95(0.84-1.08)$ & \\
\hline T4 (n=365) & $57 \%$ & $1.01(0.88-1.16)$ & \\
\hline $\mathrm{N}$ stage & & & 0.002 \\
\hline$N$ negative $(n=952)$ & $56 \%$ & Ref & \\
\hline N positive $(n=455)$ & $57 \%$ & $1.03(0.93-1.14)$ & \\
\hline$N X(n=221)$ & $44 \%$ & $0.78(0.67-0.91)$ & \\
\hline \multicolumn{4}{|l|}{ Treatment-related } \\
\hline $\begin{array}{l}\text { Anesthesiologist } \\
\text { volume }^{\&}\end{array}$ & & & $<0.001$ \\
\hline Q1 $(n=403)$ & $48 \%$ & $0.85(0.75-0.96)$ & \\
\hline Q2 $(n=366)$ & $57 \%$ & $1.00(0.89-1.13)$ & \\
\hline O3 $(n=362)$ & $62 \%$ & $1.12(1.00-1.25)$ & \\
\hline Q4 $(n=457)$ & $56 \%$ & Ref & \\
\hline
\end{tabular}

${ }^{*}$ Patients with NACT and/or preoperative RT ( $n=93$ ) are removed from the analysis since stage of disease is not reliable; \&anesthesiologist volume was classified based on the mean number of cystectomy and colorectal resections over a five-year study period (volume data were not available for 40 patients). Cl: confidence interval; NACT: neoadjuvant chemotherapy RR: relative risk; RT: radiotherapy.

epidural analgesia and those who received other perioperative pain management strategies.

Although early retrospective studies ${ }^{13-15}$ suggesting attenuation of cancer recurrence for patients undergoing surgery receiving epidural analgesia were encouraging, the studies were all retrospective in nature and consisted of small sample sizes $(n=129-655)$. Subsequent literature has been less promising and several recent studies have called into question the initial optimism regarding improved cancer outcomes. ${ }^{19,20}$ Weingarten et al ${ }^{33}$ recently published on their series of 129 patients undergoing RC with combined general anesthetic (GA) and TEA and compared to age-matched

\begin{tabular}{|c|c|c|c|}
\hline & \multicolumn{2}{|c|}{ Epidural } & \multirow[t]{2}{*}{ p value } \\
\hline & $\begin{array}{c}\text { Yes } \\
\mathrm{n}=887\end{array}$ & $\begin{array}{c}\text { No } \\
n=741\end{array}$ & \\
\hline \multicolumn{4}{|l|}{ Outcome } \\
\hline Mean LOS (days) & 14 & 14 & 0.406 \\
\hline Median LOS (days) & 10 & 10 & 0.651 \\
\hline 30-day mortality & $23(3 \%)$ & $24(3 \%)$ & 0.438 \\
\hline 90-day mortality & $63(7 \%)$ & $69(9 \%)$ & 0.104 \\
\hline 30-day re-admission ${ }^{\#}$ & $193(22 \%)$ & $183(25 \%)$ & 0.161 \\
\hline 90-day re-admission ${ }^{\#}$ & $306(34 \%)$ & $258(35 \%)$ & 0.893 \\
\hline 5-year OS $(95 \% \mathrm{Cl})$ & $41 \%(38-45 \%)$ & $37 \%(34-41 \%)$ & 0.127 \\
\hline 5-year CSS $(95 \% \mathrm{Cl}) *$ & $52 \%(48-55 \%)$ & $52 \%(48-56 \%)$ & 0.937 \\
\hline
\end{tabular}

controls undergoing oncologic surgery with only GA. In this analysis, they found no association between TEA and cancer recurrence, OS, or CSS. To our knowledge, this small study is the only report that evaluates the association of long-term outcomes in bladder cancer patients to modes of analgesia used.

In our large population-based study, we found no strong evidence of association between TEA and longterm survival among patients treated with RC for bladder cancer. This observation is consistent with a recent, large, population-based study in gastric cancer using the Surveillance, Epidemiology, and End Results (SEER) Program/ Medicare database. ${ }^{19}$ Cummings et al showed no association between epidural use and cancer recurrence or survival in 2745 patients undergoing resection of gastric cancer. ${ }^{19}$ Furthermore, Sun and colleagues ${ }^{20}$ recently published a meta-analysis of 18 studies evaluating the impact of epidural anesthesia on cancer outcomes. Although no bladder cancer studies were included in the meta-analysis, they found that although epidurals were associated with improved OS ( $\mathrm{HR} 0.84,95 \% \mathrm{Cl} 0.75-0.94)$, it was not associated with reduced cancer recurrence (HR 0.91, 95\% $\mathrm{Cl} 0.70-1.18)$. It should be noted that all of the cited studies failed to control for provider volume, an important quality-of-care indicator, which we were able to include in our analysis. It is, therefore, plausible that the observed association between neuraxial analgesia and OS in previous reports reflect residual confounding rather than a true biologic effect.

Our study is limited by the fact that epidural use was only classified as yes/no using physician billing records and we do not have additional information regarding the extent and effectiveness of perioperative pain control. We were, therefore, unable to stratify our patients based on degree of epidural success. Furthermore, epidural 'failure' can be multifactorial and significant, yet difficult to determine retro- 


\begin{tabular}{|c|c|c|c|}
\hline \multirow{3}{*}{ Characteristic } & \multicolumn{3}{|c|}{ 90-day mortality } \\
\hline & \multirow[t]{2}{*}{$\begin{array}{c}\text { 90-day } \\
\text { mortality }\end{array}$} & \multicolumn{2}{|c|}{ Multivariable analysis } \\
\hline & & OR (95\% Cl) & p value \\
\hline Patient-related & & & $<0.001$ \\
\hline \multicolumn{4}{|l|}{ Age } \\
\hline $20-59(n=239)$ & $3 \%$ & Ref & \\
\hline $60-69(n=386)$ & $6 \%$ & $2.08(0.90-4.81)$ & \\
\hline $70-79(n=646)$ & $8 \%$ & $2.44(1.12-5.33)$ & \\
\hline $80+(n=357)$ & $14 \%$ & $4.55(2.06-10.08)$ & \\
\hline Sex & & & 0.962 \\
\hline Male $(n=1237)$ & $8 \%$ & Ref & \\
\hline Female $(n=391)$ & $8 \%$ & $0.99(0.64-1.53)$ & \\
\hline $\begin{array}{l}\text { Charlson comorbidity } \\
\text { score }\end{array}$ & & & 0.242 \\
\hline $0(n=1161)$ & $7 \%$ & Ref & \\
\hline $1(n=260)$ & $10 \%$ & $1.28(0.79-2.09)$ & \\
\hline $2+(n=207)$ & $13 \%$ & $1.48(0.90-2.42)$ & \\
\hline \multicolumn{4}{|l|}{ Disease-related } \\
\hline T stage & & & $<0.001$ \\
\hline$<\mathrm{T} 2(\mathrm{n}=359)$ & $4 \%$ & Ref & \\
\hline T2 $(n=320)$ & $5 \%$ & $1.24(0.57-2.69)$ & \\
\hline T3 $(n=584)$ & $8 \%$ & $1.82(0.95-3.50)$ & \\
\hline$T 4(n=365)$ & $16 \%$ & $3.86(2.00-7.47)$ & \\
\hline $\mathrm{N}$ stage & & & 0.008 \\
\hline$N$ negative $(n=952)$ & $5 \%$ & Ref & \\
\hline$N$ positive $(n=455)$ & $12 \%$ & $1.91(1.24-2.95)$ & \\
\hline$N X(n=221)$ & $12 \%$ & $1.75(1.05-2.94)$ & \\
\hline \multicolumn{4}{|l|}{ Treatment-related } \\
\hline Surgeon volume ${ }^{\&}$ & & & 0.042 \\
\hline Q1 (n=276) & $11 \%$ & $1.73(0.98-3.05)$ & \\
\hline Q2 ( $(n=387)$ & $7 \%$ & $1.15(0.66-2.02)$ & \\
\hline Q3 $(n=434)$ & $11 \%$ & $1.90(1.15-3.15)$ & \\
\hline $\mathrm{Q} 4(\mathrm{n}=528)$ & $5 \%$ & Ref & \\
\hline Epidural & & & 0.115 \\
\hline Yes $(n=887)$ & $7 \%$ & $0.74(0.51-1.08)$ & \\
\hline No $(n=741)$ & $9 \%$ & Ref & \\
\hline \multicolumn{4}{|c|}{ 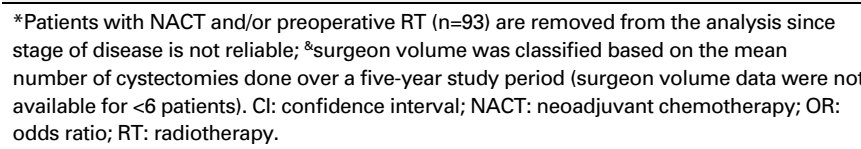 } \\
\hline
\end{tabular}

spectively. We must assume that some patients would have received an epidural that did not function optimally or were misplaced entirely and were, therefore, transitioned to IV PCA; however, there is no way to capture this information from a database. We used related colorectal procedures in their total volume determination, as these procedures burden patients with similar amounts of perioperative pain and complications and similar skill-sets in managing these patients perioperatively are required. Finally, our study is further limited through unmeasured confounding variables present in any retrospective observational study. Despite this, our study includes all patients with bladder cancer treated with curative intent RC in the province of Ontario, minimizing the referral and selection biases of single-centre series or institution-based observational studies.

\section{Conclusion}

In this population-based cohort of cystectomy patients treated between 2004 and 2008, 56\% $(n=887)$ received TEA. High-volume providers used TEA more commonly. Our data was unable to demonstrate any association between epidural use and short-term outcomes or long-term survival among patients treated with $\mathrm{RC}$ in routine clinical practice.

Competing interests: The authors report no competing personal or financial interests.

Acknowledgements: Parts of this material are based on data and information provided by Cancer Care Ontario and $\mathrm{CIHI}$. However, the analysis, conclusions, opinions and statements expressed herein are those of the authors and not necessarily those of Cancer Care Ontario or CIHI. This study was supported by the Institute for Clinical Evaluative Sciences, which is funded by an annual grant from the Ontario Ministry of Health and Long-Term Care. The opinions, results, and conclusions reported in this paper are those of the authors and are independent from the funding sources. No endorsement by Institute for Clinical Evaluative Sciences or the Ontario Ministry of Health and Long-Term Care is intended or should be inferred.

Funding: This work was supported by the Canada Foundation for Innovation. Dr. Booth is supported as the Canada Research Chair in Population Cancer Care.

This paper has been peer-reviewed.

\section{References}

1. Leveridge MJ, Siemens DR, Mackillop WJ, et al. Radical cystectomy and adiuvant chemotherapy for bladder cancer in the elderly: A population-based study. Urology 2015;85:791-8. http://dx.doi.org/10.1016/i. urology.2014.12.027

2. Froehner M, Brausi MA, Herr HW, et al. Complications following radical cystectomy for bladder cancer in the elderly. Eur Urol 2009;56:443-54. http://dx.doi.org/10.1016/i.eururo.2009.05.008

3. Stein JP, Lieskovsky $G$, Cote $R$, et al. Radical cystectomy in the treatment of invasive bladder cancer: Long-term results in 1054 patients. J Clin Oncol 2001;19:666-75.

4. Novotny V, Hakenberg OW, Wiessner D, et al. Perioperative complications of radical cystectomy in a contemporary series. Eur Urol 2007;51:397-402. http://dx.doi.org/10.1016/i.eururo.2006.06.014

5. Stimson CJ, Chang SS, Barocas DA, et al. Early and late perioperative outcomes following radical cystectomy: 90-day readmissions, morbidity, and mortality in a contemporary series. J Urol 2010;184:12961300. http://dx.doi.org/10.1016/i.juro.2010.06.007

6. Hudcova J, McNicol E, Quah C, et al. Patient-controlled opioid analgesia vs. conventional opioid analgesia for postoperative pain. Cochrane Database Syst Rev 2006;Cd003348. http://dx.doi. org/10.1002/14651858.cd003348.pub2

7. Walder B, Schafer M, Henzi I, et al. Efficacy and safety of patient-controlled opioid analgesia for acute postoperative pain. A quantitative systematic review. Acta Anaesthesiol Scand 2001;45:795-804. http://dx.doi.org/10.1034/i.1399-6576.2001.045007795.x 
Doiron et al.

\begin{tabular}{|c|c|c|c|c|c|c|}
\hline \multirow{3}{*}{ Characteristic } & \multicolumn{3}{|c|}{ CSS } & \multicolumn{3}{|c|}{ OS } \\
\hline & \multirow[t]{2}{*}{ 5-year CSS } & \multicolumn{2}{|c|}{ Multivariable analysis } & \multirow[t]{2}{*}{ 5-year OS } & \multicolumn{2}{|c|}{ Multivariable analysis } \\
\hline & & HR (95\% Cl) & p value & & HR (95\% Cl) & $p$ value \\
\hline \multicolumn{7}{|l|}{ Patient-related } \\
\hline Age & & & 0.210 & & & $<0.001$ \\
\hline $20-59(n=239)$ & $58 \%$ & Ref & & $53 \%$ & Ref & \\
\hline $60-69(n=386)$ & $51 \%$ & $1.22(0.93-1.60)$ & & $45 \%$ & $1.31(1.04-1.65)$ & \\
\hline $70-79(n=646)$ & $48 \%$ & $1.29(1.00-1.65)$ & & $39 \%$ & $1.46(1.18-1.80)$ & \\
\hline $80+(n=357)$ & $40 \%$ & $1.32(1.00-1.75)$ & & $26 \%$ & $1.78(1.41-2.24)$ & \\
\hline Sex & & & 0.189 & & & 0.223 \\
\hline Male $(n=1237)$ & $50 \%$ & Ref & & $40 \%$ & Ref & \\
\hline Female $(n=391)$ & $45 \%$ & $1.13(0.94-1.35)$ & & $37 \%$ & $1.09(0.95-1.27)$ & \\
\hline Charlson comorbidity score & & & 0.005 & & & $<0.001$ \\
\hline $0(n=1161)$ & $51 \%$ & Ref & & $43 \%$ & Ref & \\
\hline $1(n=260)$ & $49 \%$ & $0.96(0.77-1.19)$ & & $39 \%$ & $1.01(0.85-1.20)$ & \\
\hline $2+(n=207)$ & $31 \%$ & $1.43(1.14-1.79)$ & & $21 \%$ & $1.56(1.31-1.86)$ & \\
\hline \multicolumn{7}{|l|}{ Disease-related } \\
\hline T stage & & & $<0.001$ & & & $<0.001$ \\
\hline$<\mathrm{T} 2(\mathrm{n}=359)$ & $78 \%$ & Ref & & $67 \%$ & Ref & \\
\hline$T 2(n=320)$ & $61 \%$ & $1.89(1.36-2.61)$ & & $55 \%$ & $1.54(1.21-1.95)$ & \\
\hline T3 $(n=584)$ & $38 \%$ & $3.53(2.65-4.71)$ & & $29 \%$ & $2.65(2.15-3.26)$ & \\
\hline$T 4(n=365)$ & $22 \%$ & $5.62(4.15-7.61)$ & & $15 \%$ & $4.30(3.44-5.38)$ & \\
\hline $\mathrm{N}$ stage & & & $<0.001$ & & & $<0.001$ \\
\hline$N$ negative $(n=952$ ) & $63 \%$ & Ref & & $53 \%$ & Ref & \\
\hline$N$ positive $(n=455)$ & $26 \%$ & $2.35(1.93-2.86)$ & & $20 \%$ & $2.24(1.91-2.63)$ & \\
\hline$N X(n=221)$ & $32 \%$ & $1.95(1.56-2.44)$ & & $24 \%$ & $1.74(1.45-2.09)$ & \\
\hline \multicolumn{7}{|l|}{ Treatment-related } \\
\hline Surgeon volume ${ }^{\&}$ & & & 0.002 & & & $<0.001$ \\
\hline Q1 ( $n=276)$ & $43 \%$ & $1.27(1.00-1.61)$ & & $36 \%$ & $1.25(1.03-1.52)$ & \\
\hline Q2 (n=387) & $43 \%$ & $1.51(1.22-1.87)$ & & $34 \%$ & $1.44(1.21-1.71)$ & \\
\hline Q3 $(n=434)$ & $43 \%$ & $1.31(1.06-1.63)$ & & $35 \%$ & $1.38(1.17-1.64)$ & \\
\hline $\mathrm{Q} 4(\mathrm{n}=528)$ & $60 \%$ & Ref & & $50 \%$ & Ref & \\
\hline Adjuvant chemotherapy & & & 0.004 & & & $<0.001$ \\
\hline Yes $(n=282)$ & $42 \%$ & $0.72(0.58-0.90)$ & & $35 \%$ & $0.65(0.54-0.79)$ & \\
\hline No $(n=1346)$ & $50 \%$ & Ref & & $41 \%$ & Ref & \\
\hline Epidural & & & 0.804 & & & 0.136 \\
\hline Yes $(n=887)$ & $49 \%$ & $1.02(0.87-1.19)$ & & $41 \%$ & $0.91(0.80-1.03)$ & \\
\hline No $(n=741)$ & $48 \%$ & Ref & & $37 \%$ & Ref & \\
\hline
\end{tabular}

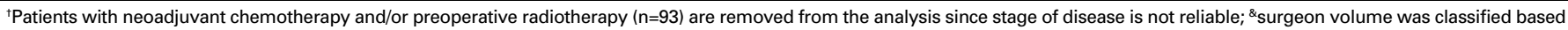

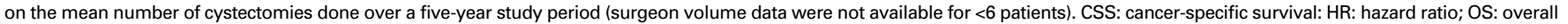
survival.

8. Carli F, Trudel JL, Belliveau P. The effect of intraoperative thoracic epidural anesthesia and postoperative analgesia on bowel function after colorectal surgery: A prospective, randomized trial. Dis Colon Rectum 2001;44:1083-9. http://dx.doi.org/10.1007/BF02234626

9. Rigg JR, Jamrozik K, Myles PS, et al. Epidural anaesthesia and analgesia and outcome of major surgery: A randomized trial. Lancet 2002;359:1276-82. http://dx.doi.org/10.1016/S0140-6736(02)08266-1

10. Melnyk M, Casey RG, Black $P$, et al. Enhanced recovery after surgery (ERAS) protocols: Time to change practice? Can Urol Assoc J 2011;5:342-8. http://dx.doi.org/10.5489/cuaj.11002

11. Cerantola Y, Valerio M, Persson B, et al. Guidelines for perioperative care after radical cystectomy for bladder cancer: Enhanced Recovery After Surgery (ERAS) society recommendations. Clin Nutr 2013;32:879-87. http://dx.doi.org/10.1016/i.clnu.2013.09.014

12. Kassouf $W$, Aprikian $A$, Black $P$, et al. Recommendations for the improvement of bladder cancer quality of care in Canada: A consensus document reviewed and endorsed by Bladder Cancer Canada (BCC), Canadian Urologic Oncology Group (CUOG), and Canadian Urological Association (CUA), December 2015. Can Urol Assoc J 2016;10:E46-80. http://dx.doi.org/10.5489/cuaj.3583
13. Exadaktylos AK, Buggy DJ, Moriarty DC, et al. Can anesthetic technique for primary breast cancer surgery affect recurrence or metastasis? Anesthesiology 2006;105:660-4. http://dx.doi.org/10.1097/00000542-200610000-00008

14. Biki B, Mascha E, Moriarty DC, et al. Anesthetic technique for radical prostatectomy surgery affects cancer recurrence: A retrospective analysis. Anesthesiology 2008;109:180-7. http://dx.doi.org/10.1097/ ALN.0b013e31817f5b73

15. Christopherson $R$, James KE, Tableman $M$, et al. Long-term survival after colon cancer surgery: A variation associated with choice of anesthesia. Anesth Analg 2008;107:325-32. http://dx.doi.org/10.1213/ ane.0b013e3181770f55

16. Camara 0 , Kavallaris $A$, Noschel $H$, et al. Seeding of epithelial cells into circulation during surgery for breast cancer: The fate of malignant and benign mobilized cells. World J Surg Oncol 2006;4:67. http:// dx.doi.org/10.1186/1477-7819-4-67

17. Dunn GP, Old U, Schreiber RD. The immunobiology of cancer immunosurveillance and immunoediting. Immunity 2004;21:137-48. http://dx.doi.org/10.1016/j.immuni.2004.07.017 
18. O'Riain SC, Buggy DJ, Kerin MJ, et al. Inhibition of the stress response to breast cancer surgery by regional anesthesia and analgesia does not affect vascular endothelial growth factor and prostaglandin $\mathrm{E}$. Anesth Analg 2005;100:244-9. http://dx.doi.org/10.1213/01.ANE.0000143336.37946.7D

19. Cummings $K C$, Patel $M$, Than Htoo P, et al. A comparison of the effects of epidural analgesia vs. traditional pain management on outcomes after gastric cancer resection: A population-based study. Reg Anesth Pain Med 2014;39:200-7. http://dx.doi.org/10.1097/AAP.0000000000000079

20. Sun Y, Li T, Gan TJ. The effects of perioperative regional anesthesia and analgesia on cancer recurrence and survival after oncology surgery: A systematic review and meta-analysis. Reg Anesth Pain Med 2015;40:110. http://dx.doi.org/10.1097/AAP.0000000000000273

21. Robles SC, Marrett LD, Clarke EA, et al. An application of capture-recapture methods to the estimation of completeness of cancer registration. J Clin Epidemiol 1988;41:495-501. http://dx.doi. org/10.1016/0895-4356(88)90052-2

22. Booth CM, Li G, Zhang-Salomons, J, et al. The impact of socioeconomic status on stage of cancer at diagnosis and survival. Cancer 2010;116:4160-7. http://dx.doi.org/10.1002/cncr.25427

23. Williams J, Young W. A summary of studies on the quality of healthcare administrative databases in Canada. In: Goel V, Williams JI, Anderson GM, Blackstien-Hirsch P, Fooks C, Naylor CD (eds). Patterns of healthcare in Ontario: The ICES Practice Attas. Ottawa: Canadian Medical Association, 1996:339-45.

24. Charlson ME, Pompei P, Ales KL, et al. A new method of classifying prognostic comorbidity in longitudinal studies: Development and validation. J Chronic Dis 1987;40:373-83. http://dx.doi.org/10.1016/00219681(87)90171-8

25. Deyo RA, Cherkin DC, Ciol MA. Adapting a clinical comorbidity index for use with ICD-9-CM administrative databases. J Clin Epidemiol 1992;45:613-9. http://dx.doi.org/10.1016/0895-4356(92)90133-8

26. Booth, $C M$, Siemens DR. Delivering high-quality care to patients with muscle-invasive bladder cancer: Insights from routine practice in Ontario. Can Urol Assoc J 2014;8:297-9. http://dx.doi.org/10.5489/ cuaj.2339
27. Siemens DR, Mackillop WJ, Peng Y, et al. Processes of care and the impact of surgical volumes on cancerspecific survival: A population-based study in bladder cancer. Urology 2014;84:1049-57. http://dx.doi. org/10.1016/i.urology.2014.06.070

28. Patafio FM, Siemens DR, Wei $X$, et al. Is there a gender effect in bladder cancer? A population-based study of practice outcomes. Can Urol Assoc J 2015;9:269-74. http://dx.doi.org/10.5489/cuaj.2927

29. Maffezzini $M$, Campodonico $F$, Capponi $G$, et al. Fast-track surgery and technical nuances to reduce complications after radical cystectomy and intestinal urinary diversion with the modified Indiana pouch. Surg Oncol 2012;21:191-5. http://dx.doi.org/10.1016/i.suronc.2012.02.001

30. Toren P, Ladak S, McCluskey $S$, et al. Comparison of epidural and intravenous patient-controlled analgesia in patients undergoing radical cystectomy. Can I Urol 2009;16:4716-20.

31. Gomez AMA, Clarke C, Smith D, et al. Is postoperative epidural analgesia better than patient-controlled analgesia for radical cystectomy? J Clin Urol 2014;7:190-7. http://dx.doi.org/10.1177/2051415813500954

32. Winer AG, Sfakianos JP, Puttanniah VG, et al. Comparison of perioperative outcomes for epidural vs. intravenous patient-controlled analgesia after radical cystectomy. Reg Anesth Pain Med 2015;40:239-44. http://dx.doi.org/10.1097/AAP.0000000000000219

33. Weingarten TN, Taccolini AM, Ahle ST, et al. Perioperative management and oncological outcomes following radical cystectomy for bladder cancer: A matched retrospective cohort study. Can J Anesth 2016;63:58495. http://dx.doi.org/10.1007/s12630-016-0599-9

Correspondence: Dr. D. Robert Siemens, Kingston General Hospital, Kingston, ON, Canada; siemensr@kgh.kari.net 